\title{
Czy neopatrystyka była rosyjskim renesansem patrystycznym? Recenzja książki Filozofia rosyjskiego renesansu patrystycznego
}

\author{
ks. d. Łukasz Leonkiewicz \\ Prawosławne Seminarium Duchowne w Warszawie \\ Polska \\ lukasz_leon@poczta.onet.pl
}

Rev. Łukasz Leonkiewicz, Does the neopatristical synthesis is a Russian renaissance of patristic? Book Review "Philosophy of Russian renaissance of patristic, Elpis, 17 2015: 159-161.

W drugiej połowie 2014 roku na polskim rynku wydawniczym pojawiła się książka poświęcona XX-wiecznej myśli prawosławnej autorstwa krakowskiej badawczyni myśli rosyjskiej s. Teresy Obolevitch. Pozycja nosi tytuł Filozofia rosyjskiego renesansu patrystycznego, a w swej treści poświęcona jest prezentacji poglądów dwóch bardzo ważnych, jeśli nie najważniejszych, prawosławnych teologów XX wieku - o. Jerzego Florowskiego oraz Włodzimierza Łosskiego.

Obaj myśliciele, co podkreśla autorka, ale i inni badacze myśli prawosławnej ${ }^{1}$, uważani są za założycieli bądź odrodzicieli nowego teologicznego myślenia prawosławnego w XX wieku. Prace i działalność naukowa Jerzego Florowskiego i Włodzimierza Łosskiego legły u podstaw tzw. syntezy neopatrystycznej, czy może po prostu neopatrystyki, którą autorka nazywa „rosyjskim renesansem patrystycznym”. S. Teresa w swej książce stara się rosyjski renesans patrystyczny wywieść z rosyjskiej filozofii religijnej, której założycielem i głównym przedstawicielem jest Włodzimierz Sołowjow. Próbie tej poświęcony jest cały pierwszy rozdział książki. Autorka, znana w środowisku badaczy myśli rosyjskiej przede wszystkim z zainteresowań rosyjską filozofią religijną, w szczególności okresem tzw. Srebrnego Wieku, po raz pierwszy wychodzi po za ramy Srebrnego Wieku i poza ramy filozofii rosyjskiej w ogóle. Neopatrystyka jest bowiem przedsięwzięciem nierosyjskim, a może lepiej nie tylko rosyjskim, a już z pewnością nie wywodzi się w sposób bezpośredni z filozofii religijnej. Okres neoaptrystyki dotychczas był pomijany w polskich badaniach nad myślą rosyjską. Spowodowane to było, po części, negatywnym stosunkiem myślicieli-teologów neopatrystycznych wobec filozofii rosyjskiej, jak i podejrzliwym stosunkiem samych filozofów religijnych wobec nowego, a w istocie swej teologicznego nurtu, myśli religijnej. Powszechnie znana opinia Mikołaja Bierdiajewa na temat książki Jerzego Florow-

С. Хоружий, Неопатристический синтез и русская философия, [w:] О старом и новом, АЛЕТЕЙЯ, Санкт-Петербург 2000, s.35-61. skiego pt. Drogi filozofii rosyjskiej² wyraża ogólną opinię rosyjskiego środowiska filozoficznego na emigracji wobec nowego nurtu w teologii rosyjskiej. Ponadto opinia ta do dziś wywiera ogromny wpływ na środowisko polskich badaczy myśli rosyjskiej, którzy z przekąsem traktują prawosławną myśl teologiczną XX wieku, a której protoplastą był wspomniany już o. Jerzy Florowski. Podjęta przez niego próba odrodzenia myślenia patrystycznego zasługuje na przyrównanie go do innego wielkiego myśliciela XX wieku, próbującego odrodzić już nie teologiczne czy religijne, ale filozoficzne myślenie, do samego wielkiego Martina Heideggera. Zarówno pod względem czasowym, jak i ideowym tych dwóch myślicieli należy postrzegać integralnie, wraz z renesansem tomistycznym w teologii katolickiej czy odrodzeniem myśli protestanckiej w twórczości P. Tillicha, D. Bonhoeffera, K. Bartha.

Tymczasem s. Teresa Obolevitch wbrew ogólnie przyjętej zasadzie w swej ostatniej książce zajęła się tym nietradycyjnym wśród badaczy myśli rosyjskiej w Polsce tematem. Warto także podkreślić, że zajmując się tematyką neopatrystyki autorka wniosła istotny wkład do polskich badań nad filozofią rosyjską. Jako pierwsza zrobiła krok ku nowym badaniom nad filozofią rosyjską, badaniom, które nie będą obracały się w kręgu rosyjskiej myśli XIX-wiecznej bądź w kręgu rosyjskiego Srebrnego Wieku, lecz uwzględnią wszystko to, co wyrosło z filozofii rosyjskiej w XX wie$\mathrm{ku}$, nawet jeśli to nowe myślenie zanegowało i odrzuciło fundamenty swoich poprzedników, nazywając ich po prostu „marzycielami””. Przy badaniach współczesnej myśli rosyjskiej należy także pamiętać, iż, opisywana w książce s. Teresy, neopatrystyka nie jest już bynajmniej fenomenem teraźniejszym. Renesans neopatrystyczny wciąż dokonuje się na gruncie teologicznym czy religijnym, ale na gruncie filozoficznym jest już, pod pewnym względem, fenome-

\footnotetext{
Wyrażając opinię o książce J. Florowskiego M. Bierdiajew stwierdził, że powinna ona nosić tytuł „Bezdroża teologii rosyjskiej”, bowiem, temu właśnie była poświęcona.

3 С. Хоружий, О старом и новом, dz.cyt., s. 167.
} 
nem historycznym. Odrodzenie patrystyki, myślenia patrystycznego, głoszone przez Florowskiego, miało być „powrotem do przeszłości, do Ojców Kościoła, dzięki któremu możliwy jest postęp". Ów postęp miałby polegać na obraniu patrystycznych fundamentów pod nowe myślenie prawosławne, teologiczne, religijne. Tak jak filozofia $\mathrm{w}$ pracach

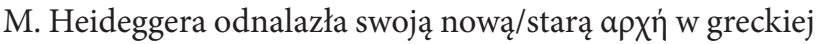
starożytności, tak teologia prawosławna swą nową/starą a $\chi \eta \dot{~ o d n a l a z ł a ~ w ~ g r e c k i e j ~ p a t r y s t y c e . ~ N a ~ t e j ~ n o w e j / s t a r e j ~}$ zasadzie, nowym fundamencie, który odsłonięty został przez teologów nurtu neopatrystycznego już dziś budują swoje koncepcje myśliciele prawosławni, nie tylko rosyjscy, ale również greccy, serbscy i inni. Tym bardziej cieszy fakt podsumowania idei renesansu neopatrystycznego w myśli prawosławnej przez s. Teresę Obolevitch.

Powróćmy jednak do recenzji. W pierwszym rozdziale autorka, co już powyżej wspomniałem, stara się pokazać ciągłość myśli rosyjskiej i z XIX-wiecznej filozofii rosyjskiej wywodzi renesans neopatrystyczny. Trafnie dobrane i dostrzeżone zostały wątki wspólne neopatrystyce i poprzedzającej ją filozofii religijnej. Zarówno imiesławie, jak i kwestia sofilogiczna rzeczywiście podnoszą problemy patrystyczne, ale ich rozwiązanie zaproponowane przez poszczególnych myślicieli rosyjskich dalekie są od rozwiązania patrystycznego, co bardzo trafnie podkreśla autorka książki: „Spory wokół onomatodoksji wyraźnie pokazały, że w kręgach rosyjskich intelektualistów słabo znano tradycję hezychastyczno-patrystyczną" (s. 49). Słaba znajomość dotyczy jednak tych wszystkich zwolenników imiesławia, którzy dokonali filozoficznej interpretacji tej kwestii odwołując się nie do myślenia patrystycznego, lecz do myślenia neoplatońskiego. Autorka opisując tę kwestię trafnie zauważyła, że J. Florowski „nie uznawał ontologicznego, realnego charakteru imienia, wyrażając przekonanie, iż każda formuła lingwistyczna, $\mathrm{w}$ tym stwierdzenie onomatodoksów $w$ imieniu Bożym jest sam Bóg, zostaje uświęcona wyłącznie przez fakt obcowania $z$ Bogiem, a nie mocą samego słowa" (s. 47).

Inną kwestią wspólną rosyjskiej filozofii religijnej i neopatrystyce jest sofiologia, przede wszystkim w wydaniu S. Bułgakowa. Autorka trafnie opisuje różnicę w podejściu do kwestii pośrednictwa między Bogiem a człowiekiem/światem w ujęciu S. Bułgakowa oraz Florkowskiego i Łosskiego. Obaj neopatryści w dość wyraźny sposób odżegnywali się od substancjalnego podejścia filozofów religijnych, którzy w swych systemach starali się połączyć Boga ze światem na poziomie istotowym i pokazywali, że w patrystyce spotykamy się z innym opisem, z innym ujęciem relacji Bóg-świat, która realizuje się na poziomie energicznym, na poziomie działań, a nie substancji. Jak pisze autorka: „Tymczasem Florowski i Łosski dążyli do rozwijania całej teologii rosyjskiej w tym właśnie kierunku, który wyznaczył św. Grzegorz Palamas i jego poprzednicy. (...) spekulatywne, metafizyczne podejście do prawd wiary chrześcijańskiej, rozpoczęte przez Sołowjowa i kontynuowane przez Bułgakowa, było przedmiotem nieustannej krytyki ze strony Florowskiego i Łosskiego..." (s. 61).

Ostatni cytat w dość wyraźny sposób przemawia i za tym, że rozpoczęta przez Florowskiego i Łosskiego próba odrodzenia myślenia patrystycznego w XX wieku nie ma tylko i wyłącznie rosyjskiego charakteru. Wręcz przeciwnie, to przez krytykę tego, co było owocem myśli rosyjskiej, imiesławia i sofiologii, pojawiła się myśl neopatrystyczna. Renesans neopatrystyczny z tego powodu nie może być nazwany „rosyjskim”. Co prawda to rosyjscy myśliciele Florowski, Łosski, Krywoszein - uznawani są za prekursorów myślenia tego typu, ale zaproponowany przez nich styl i sposób filozofowania czy teologizowania zakorzenił się w całej teologii prawosławnej - nie rosyjskiej czy greckiej, ale prawosławnej w ogóle. Dlatego też omawianych w książce s. Teresy myślicieli należy traktować nie jako przedstawicieli myśli rosyjskiej w jej neopatrystycznym nurcie, lecz jako przedstawicieli teologii prawosławnej, którzy swoją pozycję ukonstytuowali w opozycji wobec przyjętego w filozofii rosyjskiej sposobu myślenia religijnego. Rosyjska myśl religijna i teologia neopatrystyczna mają się do siebie tak, jak neoplatonizm i teologia bizantyjska. Jak dobrze pamiętamy neoplatonizm kilkakrotnie był anatematyzowany przez przedstawicieli teologii bizantyjskiej (np. w roku 553 czy 1076).

W rozdziale drugim i trzecim prezentowane są sylwetki Jerzego Florowskiego i Włodzimierza Łosskiego. Nie sposób znaleźć w tym miejscu książki jakiekolwiek „usterki”. Osobowości obydwu myślicieli, ich biografie i poglądy są przedstawione wzorowo. Na szczególną uwagę zasługuje fakt bardzo dużej ilości cytatów pochodzących ze źródeł trudnodostępnych dla przeciętnego czytelnika. Czytając rozdziały o Florowskim i Łosskim nawet absolutny laik $\mathrm{w}$ tematyce jest $\mathrm{w}$ stanie zbudować całościowy, przejrzysty obraz myśli obu teologów. Prostota i precyzyjność wykładu nie przeszkadza bynajmniej czytelnikowi bardziej zaawansowanemu w lekturze filozoficznej. W książce można znaleźć bardzo dużo szczegółowych informacji bibliograficznych, precyzyjny wykład poglądów opatrzony komentarzem autorki, który niejednokrotnie zmusza, a nawet zachęca do zastanowienia się nad omawianymi kwestiami. Ponadto autorce udało się zachować filozoficzny wymiar wykładu. Nie poprzestaje bowiem na opisaniu poglądów każdego z myślicieli, ale te poglądy układa w spójny system, który wcale niełatwo jest odtworzyć w oparciu jedynie o artykuły analizowanych myślicieli.

Wysiłek o. J. Florowskiego poświęcony został stworzeniu „syntezy neopatrystycznej”. S. Teresa bardzo precyzyjnie opisała ten projekt i umiejscowiła go na tle myśli rosyjskiej. Dostrzegła wpływy słowianofilstwa oraz euroazjatyzmu na myśl Florowskiego, wskazując również różnice między neopatrystyką i wspomnianymi nurtami myśli rosyjskiej. „Synteza neopatrystyczna” polegać miała na odrodzeniu stylu patrystycznego, na odrodzeniu „ducha Ojców” i jak czytamy w książce warunkami tego odrodzenia miały być: „soborowość, powrót do dziedzictwa Ojców, hellenizm chrześcijański i historyzm” (s.122). Autorka książki podkreśla, że współczesne myślenie religijne w opinii Florowskiego powinno być zaangażowane w swą własną historię jako przeszłość i przyszłość zarazem, powinno odpowiadać autentycznemu doświadczeniu chrześcijańskiemu przekazanemu nam przez apostołów i właśnie Ojców Kościoła 
oraz powinno odradzać starożytność, odradzać hellenizm chrześcijański, który rozwijał się w okresie patrystyki. Każdej z tych kwestii s. Teresa poświęciła osobny podrozdział, w którym doskonale prezentuje poglądy J. Florowskiego.

W rozdziale III książki s. Teresa Obolevitch prezentuje sylwetkę Włodzimierza Łosskiego. Zawarte w nim informacje biograficzne oraz wykład poglądów teologicznych W. Łosskiego są bardziej niż zadowalające. Autorka przedstawiła w nim kwestie ogólno filozoficzne, które nurtowały W. Łosskiego i które do dziś stanowią problem dla każdego teologa prawosławnego. Kwestie relacji filozofii wobec teologii, teologii wschodniej wobec teologii zachodniej, poznania Boga i Jego niepoznawalności, opisu doświadczenia mistycznego na chrześcijańskim Wschodzie i Zachodzie stanowią przebogatą treść tego rozdziału. Ponadto w rozdziale tym znajdziemy analizę poglądów antropologicznych W. Łosskiego, które w rzeczy samej są syntezą patrystycznej koncepcji przebóstwienia.

Bardzo istotnym atutem tej części książki s. Teresy jest zestawienie, dokonane już przez W. Łosskiego, i porównanie poszczególnych kwestii teologicznych z punktu widzenia teologii wschodniej i zachodniej. W podrozdziale 3.3.2. Teoria analogii autorka przedstawia kwestię analogii w ujęciu Pseudo-Dionizego Areopagity oraz Mistrza Eckcharta, pokazując tym samym, jak bardzo twórcze może być wspólne, z perspektywy patrystyki greckiej, odczytanie myślicieli, którzy w istocie swej grekami nie byli. Tym samym neopatrystyka, jako poszukiwanie źródeł duchowości chrześcijańskiej staje się metodą nie tylko teologii prawosławnej, lecz metodą teologiczną w ogóle mającą na celu zbadanie, porównanie i zestawienie dwóch nurtów chrześcijaństwa - greckiego i łacińskiego. Neopatrystyka jest powrotem do źródeł myślenia religijnego, teologicznego, który jest celem postawionym przed całym światem chrześcijańskim.

W ostatnim rozdziale książki autorka prezentuje dwóch teologów prawosławnych, którzy kontynuowali dzieło J. Florowskiego i W. Łosskiego. Są nimi Bazyli Krywoszein oraz Cyprian Kern. Obaj zajmowali się patrologią, wywarli wpływ na rozwój badań nad patrystyką grecką, tłumaczyli dzieła Ojców Kościoła, redagowali je, popularyzowali. Zaprezentowanie tych dwóch postaci wprowadza czytelnika w już całkowicie inny świat - w świat recepcji idei neopatrystycznej w Kościele Prawosławnym. Krótka charakterystyka osobowości i twórczości obydwu tych myślicieli powiązana jest z gronem ich uczniów, z młodszym pokoleniem teologów, którzy już nie tylko badali dzieła Ojców Kościoła, ale w oparciu o nie tworzyli własne syntezy, rozwijali kwestie podniesione przez Ojców Kościoła, a co dla filozofa najważniejsze dyskutowali z najwybitniejszymi przedstawicielami myśli europejskiej. Autorka wspomina o J. Meyendorffie, Paulu Evdokimovie, J. Zizoulasie, Ch. Yannarasie, O. Clement, S. Chorużym, A. Nesteruku, J. Romanidesie, N. Panagiotisie i innych, którzy bezpośrednio związani są z „syntezą neopatrystyczną” bądź, którzy proponując inny sposób myślenia zapisali się w dwudziestowiecznej historii teologii prawosławnej. Pokazuje tym samym, że "filozofia rosyjskiego renesansu patrystycznego" w trakcie XX wieku stała się już ogólnoprawosławną, soborową tendencją w rozwoju nie tylko teologii prawosławnej, ale także filozofii.

Pod względem formalnym, tak jak ideowym, książce nie sposób cokolwiek zarzucić. Działo s. Teresy (Obolevitch) liczy 351 stron wraz z bibliografią i indeksami. Książka od strony graficznej wygląda bardzo dobrze. Na okładce przedstawiona została postać najbardziej charakterystyczna dla „rosyjskiego renesansu patrystycznego” - św. Grzegorz Palamas. Ów ostatni Ojciec Kościoła, jak nieraz się go nazywa, a przede wszystkim jego twórczość wywarła wielki wpływ na neopatrystykę, dlatego też wizerunek tego świętego może być swego rodzaju sztandarem „syntezy neopatrystycznej". Książka napisana jest bardzo dobrym językiem, cechuje ją przejrzystość wywodu, a przede wszystkim wszechobecna w niej potrzeba wyjścia poza dotychczasowe ramy zainteresowań polskich badaczy filozofii rosyjskiej. Pozycja ta jest pierwszym i miejmy nadzieję nie ostatnim krokiem ku „nowym” badaniom nad myślą rosyjską. Jest to pierwsza próba wyjścia poza granice rosyjskiego Srebrnego Wieku i miejmy nadzieję, że dzieło to będzie kontynuowane przez innych badaczy myśli wschodniej. 
ISSN 1508-7719

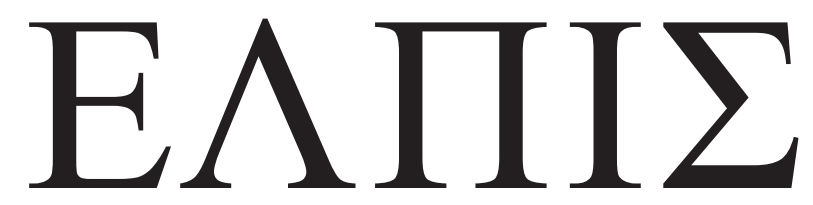

CZASOPISMO TEOLOGICZNE KATEDRY TEOLOGII PRAWOSŁAWNEJ UNIWERSYTETU W BIAŁYMSTOKU

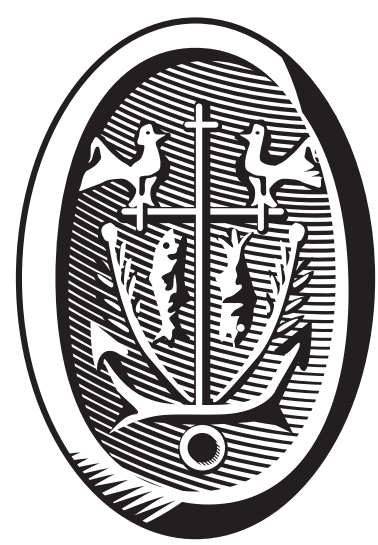

ADRES REDAKCJI

15-097 Białystok, ul. M. Skłodowskiej-Curie 14 tel. 85 745-77-80, e-mail: redakcja@elpis.edu.pl www.elpis.uwb.edu.pl 